\title{
A Study on the Bacterial Profile of Urinary Tract Infection in Antenatal Cases Attending a Tertiary Care Unit
}

\author{
T.G. Anjaleena ${ }^{1}$, O. Sasikumari ${ }^{1 *}$ and T. Gopakumar ${ }^{2}$ \\ ${ }^{1}$ Department of Microbiology, ${ }^{2}$ Department of MLT, Goverment Medical College, \\ Thiruvananthapuram, India \\ *Corresponding author email id:
}

\begin{tabular}{|c|c|}
\hline & A B S T R A C T \\
\hline Keywords & \multirow{4}{*}{$\begin{array}{l}\text { A descriptive study was conducted to study the bacterial profile of urinary } \\
\text { tract infection in antenatal cases attending a tertiary care unit. The study } \\
\text { period was for six months. Totally } 246 \text { antenatal women were screened for } \\
\text { urinary tract infection. Of them } 32(13 \%) \text { were culture positive. E. coli was } \\
\text { the most common isolate. Females of } 26-30 \text { years of age were most } \\
\text { commonly affected, } 12 \text { cases }(37.5) \text {. Urinary tract infection was more } \\
\text { common during third trimester of pregnancy }\end{array}$} \\
\hline $\begin{array}{l}\text { Bacterial profile, } \\
\text { Urinary tract } \\
\text { infection. }\end{array}$ & \\
\hline Article Info & \\
\hline $\begin{array}{l}\text { Accepted: } \\
\text { 23 June } 2017 \\
\text { Available Online: } \\
\text { 10 July } 2017\end{array}$ & \\
\hline
\end{tabular}

\section{Introduction}

Urinary Tract Infection (UTI) is one of the most common type of infection in the body, accounting for about 8.1 million visits to health care providers for each year (Urinary tract infections in adults; national kidney and urologic diseases information clearing house, US Department of Health and Human services; Schappert et al., 2006). Women are especially prone to UTIs due to anatomical reasons. For women the life time risk of acquiring UTI is greater than 50 percent (Griebling, 2007). Pregnant women seem to be more prone to infections. Pregnancy causes numerous changes in the body. Hormonal and mechanical changes increase the risk of urinary stasis and vesico ureteral reflux. These changes along with an already short urethra $(\sim 3-4 \mathrm{~cm})$ and improper hygiene due to a distended pregnant belly, increases the frequency of Urinary Tract Infections in pregnant women (Emily, 2014). Pregnant females are immuno-compromised because of the physiologic changes associated with pregnancy. These changes increase the risk of serious complications from symptomatic and asymptomatic urinary infections even in healthy pregnant women (Emily, 2014). If UTIs are untreated during pregnancy, it increases the risk by $20 \%$ to $40 \%$ for pyelonephritis, premature delivery, and fetal mortality (Nowiciki, 2002; Wing, 1998). Asymptomatic bacteriuria doubles the risk of pre-term delivery and/or low birth weight. UTIs during third trimester increase the 
relative risk of mental retardation or developmental delay, as well as fetal death (Wing, 1998).

The members of the family Enterobacteriaceae, are the most frequent pathogens detected, causing $84.3 \%$ of the UTIs (Gales et al., 1998). The organisms causing UTIs during pregnancy are the same as those found in other UTI patients. Escherichia coli accounts for 80\% - 90\% infections (Hart et al., 1996), about $85 \%$ of community acquired UTIs, $50 \%$ of nosocomial UTIs and more than $80 \%$ of uncomplicated pyelonephritis (Bergerson, 1995).

Among Enterobacteriaceae, the genus Klebsiella accounts for $6 \%-17 \%$ of all nosocomial UTIs and shows an even higher incidence in specific group of patients at risk (Bennet et al., 1995). Proteus mirabilis is a common cause of UTI in individuals with long term urinary catheters in situ or individuals with complicated UTIs.

The present study focuses on the detection and incidence of UTI among pregnant women attending the antenatal clinic of Sree Avittom Thirunal (SAT)

Hospital, Thiruvananthapuram. It also focuses on the incidence, types of etiological agents, bacterial profile and their respective antibiotic susceptibility pattern.

\section{Primary objective}

To determine the bacterial profile of urinary tract infection in the urine samples of antenatal cases processed in the microbiology lab, SATH during the study period.

\section{Secondary objectives}

To speciate the common bacterial agents causing antenatal urinary tract infections.
To determine the antibiotic susceptibility pattern of the bacterial isolates.

\section{Materials and Methods}

Design of study-Descriptive study

Study period-Six months

\section{Study settings}

Clinical Microbiology laboratory, SAT Hospital, Thiruvananthapuram

Department of MLT, Govt. Medical college, Thiruvananthapuram

\section{Study population}

Antenatal cases whose urine samples have been processed in the Microbiology laboratory, SAT hospital, Thiruvananthapuram, India.

\section{Inclusion criteria}

Antenatal cases whose urine sample has been send to microbiology lab, SATH, for culture and sensitivity.

\section{Exclusion criteria}

- Improperly collected urine samples

- Fungal infections causing Urinary Tract Infection e.g. Candidiasis

- Catheterized urine sample

- $\quad$ Mixed Bacterial Growth

\section{Sample size calculation}

$$
N=\frac{Z_{1-\alpha / 2}^{2} P(1-P)}{d^{2}}
$$

$\mathrm{P}=$ Proportion of positive cases $(28.06 \%)$

$\mathrm{d}=20 \%$ of $\mathrm{P}$

$1-\alpha / 2=$ designed confidence interval (95\%)

$\mathrm{N}=246(\approx 250)$ 


\section{Materials and Methods}

A prospective study was carried out in 246 antenatal cases during the period of six months from March 2015 to September 2015. The study was conducted in the clinical microbiology laboratory in SAT Hospital, Thiruvananthapuram, Kerala. The Mid Stream Urine samples of antenatal cases sent for microbiological studies were processed

- Macroscopy: samples were checked whether it was clear, slightly turbid or turbid.

- Microscopy

Wet film preparation

- Gram staining

- Culturing of the specimen and isolation of organism on Blood agar, Mac Conkey agar and Hichrome UTI agar

- Identification and speciation of the organism was done by conventional biochemical tests

- Antibiotic susceptibility testing was done by disc diffusion method on Mueller Hinton Agar by Stokes/ Kirby-Bauer method.

\section{Results and Discussion}

The present study was carried out in the Microbiology laboratory of Sree Avittom Thirunal Hospital (SATH), Thiruvananthapuram, during a period of six months from March 2015 to August 2015. The present study evaluates the bacterial profile of isolates obtained from urine samples of antenatal cases.

Totally 246 samples from different age groups between 18-40 years were considered for the study. Out of these a total of $32(13 \%)$ isolates were obtained (Table 1). This observation seems to agree with the findings of Hamdan et al., (2010). Similar findings were observed with the studies conducted in
Tanzania by Masinde et al., (2009). The use of Hichrome agar helped in detecting and identifying the organisms on the second day itself. E. coli gave purple coloured colonies whereas Klebsiella pneumoniae gave blue coloured colonies. Staphylococcus aureus was ivory coloured on HiChrome UTI agar. It also helped to detect mixed bacterial growth at the earliest.

Regarding the age wise distribution of bacterial isolates, the maximum number of cases was in the age group of $26-30$ years (Table 2). Highest and lowest ages found to be infected were 39 years and 18 years respectively. These findings correlated with reports of Gonzalez and Schaeffer (1999) which showed similar result. The reason of increased prevalence in this age group may possibly be associated with high sexual activity and/or multiparity.

Escherichia coli was the most common isolate, 19 cases $(59.4 \%)$ (Table 3). This correlates well with the study of Manjula et al., (2013), where E. coli accounted for $56.9 \%$. Second most common agent isolated in the present study was Klebsiella pneumonia accounting for 11 cases (34.4\%).

This result is contrary to the findings of Omonigho et al., (2001) who found out that Klebsiella pneumoniae to be more prevalent than Escherichia coli in antenatal cases. The least frequently isolated organism was Staphylococcus aureus, which accounted for about two cases (6.25\%). Staphylococcus aureus was considered as an agent causing UTI only when it was isolated in repeat samples of clean catch midstream urine samples.

Studies by Kandaki-Olikemi et al., (2009) also showed that the isolation of Gram positive organism as uropathogen was less than $10 \%$. In the present study, trimester wise 
analysis showed that the rate of infection was highest during the third trimester which accounted for 14 cases $(43.8 \%)$ followed by first trimester and least frequently the second trimester (Table 4). In all the three trimesters Escherichia coli was found to be the major pathogen followed by Klebsiella pneumonia and Staphylococcus aureus. Highest frequency of UTIs in third trimester may be due to the progressive obstruction of the urinary tract following and stasis of urine due to the falling forward of uterus especially in anteverted uterus. These findings correlate with studies by Theodore (2007) from Nigeria.

Table.1 Prevalence of UTI

\begin{tabular}{|l|l|}
\hline Total samples & Bacterial isolates \\
\hline 246 & $32(13 \%)$ \\
\hline
\end{tabular}

Table.2 Age distribution of positive cases

\begin{tabular}{|l|l|l|}
\hline $\begin{array}{l}\text { AGE } \\
\text { (in years) }\end{array}$ & FREQUENCY & $\begin{array}{l}\text { PERCENTAGE } \\
(\boldsymbol{\%})\end{array}$ \\
\hline $18-20$ & 3 & 9.4 \\
\hline $21-25$ & 9 & 28.1 \\
\hline $26-30$ & 12 & 37.5 \\
\hline $31-35$ & 5 & 15.6 \\
\hline $36-40$ & 3 & 9.4 \\
\hline
\end{tabular}

Table.3 Bacterial profile of urinary isolates

\begin{tabular}{|l|l|l|}
\hline $\begin{array}{l}\text { BACTERIAL } \\
\text { ISOLATE }\end{array}$ & $\begin{array}{l}\text { FREQUENCY } \\
\text { (Number) }\end{array}$ & $\begin{array}{l}\text { PERCENTAGE } \\
(\boldsymbol{\%})\end{array}$ \\
\hline Escherichia coli & 19 & 59.4 \\
\hline Klebsiella pneumoniae & 11 & 34.4 \\
\hline Staphylococcus aureus & 2 & 6.25 \\
\hline
\end{tabular}

Table.4 Positive cases in relation with gestational age

\begin{tabular}{|l|l|l|}
\hline $\begin{array}{l}\text { GESTATIONAL AGE } \\
\text { (Trimesters) }\end{array}$ & FREQUENCY & $\begin{array}{l}\text { PERCENTAGE } \\
(\%)\end{array}$ \\
\hline $\begin{array}{l}1^{\text {st }} \text { trimester } \\
\text { (week } 1-\text { week 12) }\end{array}$ & 11 & 34.4 \\
\hline $\begin{array}{l}2^{\text {nd }} \text { trimester } \\
(\text { week 13 - week 27) }\end{array}$ & 7 & 21.9 \\
\hline $\begin{array}{l}3^{\text {rd }} \text { trimester } \\
\text { (week 28 - week 40) }\end{array}$ & 14 & 43.8 \\
\hline
\end{tabular}


Table.5 Antibiotic sensitivity pattern of bacterial isolates

\begin{tabular}{|l|l|l|l|l|l|l|}
\hline ANTIBIOTICS & $\begin{array}{l}\text { Escherichia coli } \\
(n=19)\end{array}$ & $\begin{array}{l}\text { Klebsiella } \\
\text { pneumoniae. } \\
(n=11)\end{array}$ & \multicolumn{2}{l|}{$\begin{array}{l}\text { Staphylococcus } \\
\text { aureus }(n=2)\end{array}$} \\
\hline & SENSITIVE & $\begin{array}{l}\text { RESISTAN } \\
\text { T }\end{array}$ & $\begin{array}{l}\text { SENSITIV } \\
\text { E }\end{array}$ & $\begin{array}{l}\text { RESISTAN } \\
\text { T }\end{array}$ & $\begin{array}{l}\text { SENSITIV } \\
\text { E }\end{array}$ & $\begin{array}{l}\text { RESISTAN } \\
\text { T }\end{array}$ \\
\hline Ampicillin & $\mathbf{6}$ & $\mathbf{1 3}$ & $\mathbf{0}$ & $\mathbf{1 1}$ & $\mathbf{2}$ & O \\
\hline Gentamicin & $\mathbf{6}$ & $\mathbf{1 3}$ & $\mathbf{3}$ & $\mathbf{8}$ & $\mathbf{2}$ & $\mathbf{0}$ \\
\hline Cephalexin & $\mathbf{9}$ & $\mathbf{1 0}$ & $\mathbf{6}$ & $\mathbf{5}$ & NC & NC \\
\hline Nalidixic acid & $\mathbf{7}$ & $\mathbf{1 2}$ & $\mathbf{7}$ & $\mathbf{4}$ & NC & NC \\
\hline Norfloxacin & $\mathbf{7}$ & $\mathbf{1 2}$ & $\mathbf{7}$ & $\mathbf{4}$ & NC & NC \\
\hline Co-trimoxazole & $\mathbf{8}$ & $\mathbf{1 1}$ & $\mathbf{4}$ & $\mathbf{7}$ & NC & NC \\
\hline Amikacin & $\mathbf{1 8}$ & $\mathbf{1}$ & $\mathbf{8}$ & $\mathbf{3}$ & $\mathbf{2}$ & $\mathbf{0}$ \\
\hline Ceftriaxone & $\mathbf{1 0}$ & $\mathbf{9}$ & $\mathbf{6}$ & $\mathbf{5}$ & NC & NC \\
\hline Ciprofloxacin & $\mathbf{7}$ & $\mathbf{1 2}$ & $\mathbf{8}$ & $\mathbf{3}$ & NC & NC \\
\hline $\begin{array}{l}\text { Piperacillin/Taz } \\
\text { obactum }\end{array}$ & $\mathbf{1 7}$ & $\mathbf{2}$ & $\mathbf{1 0}$ & $\mathbf{1}$ & NC & NC \\
\hline $\begin{array}{l}\text { Cefoperazone/ } \\
\text { sulbactum }\end{array}$ & $\mathbf{1 7}$ & $\mathbf{2}$ & $\mathbf{1 1}$ & $\mathbf{0}$ & NC & NC \\
\hline Imipenem & $\mathbf{1 9}$ & $\mathbf{0}$ & $\mathbf{1 1}$ & $\mathbf{0}$ & NC & NC \\
\hline Aztreonam & $\mathbf{1 7}$ & $\mathbf{2}$ & $\mathbf{1 1}$ & $\mathbf{0}$ & $\mathbf{N C}$ & NC \\
\hline Nitrofurantoin & $\mathbf{1 8}$ & $\mathbf{1}$ & $\mathbf{1 1}$ & $\mathbf{0}$ & NC & NC \\
\hline Novobiocin & NC & NC & NC & NC & $\mathbf{2}$ & $\mathbf{0}$ \\
\hline Cefoxitin & NC & NC & NC & NC & $\mathbf{2}$ & $\mathbf{0}$ \\
\hline
\end{tabular}

*NC- not checked

All the Gram negative isolates were sensitive to Imipenem 19 (100\%) (Table 5) followed by Nitrofurantoin 18 (96.7\%), Aztreonam17 (93.3\%) and Cefoperazone/Sulbactum 17 $(93.3 \%)$. The common drugs used to treat UTI in antenatal cases are Ampicillin and Cephalexin, but it is noted that 13 isolates (68\%) of E. coli were resistant to Ampicillin and 10 isolates $(52 \%)$ were resistant to Cephalexin. Among the Klebsiella pneumoniae isolated, five isolates $(46 \%)$ were resistant to Cephalexin and they are inherently resistant to Ampicillin.

Considering Gram positive isolates, they showed $100 \%$ sensitivity to Ampicillin, Cefoxitin and Aminoglycosides (Table 5).
In conclusion, UTI in pregnancy is associated with significant maternal and fetal morbidity. It is therefore recommended that routine microbiological analysis and antibiotic sensitivity test of mid stream urine samples of pregnant women be carried out so as to enhance the administration of the right drugs for treatment and prevent further complications of Urinary tract infections.

\section{References}

Bennet, C.J., M.N. Young \& H. Darrington. 1995. "Differences in urinary tract infections in male and female spinal cord injury patients on intermittent catheterization." Paraplegia, vol.33, No.2, pp 69-72. 
Bergerson, M.G. 1995. "Treatment of pyelonephritis in adults", Med. Clin. North America, vol. 75, pp. 619-649.

Emily Catherine Jhonson. 2014. Urinary tract infections in pregnancy.

Gales, C.A., R.N. Jones, K.A. Gordon, H.S. Sader, W.W. Wilke, M.L. Beach, M.A. Pfaller, G.V. Doren. 1998. The Senetry study group (Latin America), "Activity and spectrum of 22 anti microbial agents tested against urinary tract infection pathogens in hospitalized patients in Latin America Reports from the $2^{\text {nd }}$ year of Senetry anti microbial surveillance program, J. Antimicrobial Chemther., vol.45, No.3, pp 293-303.

Gonzalez, C.M. and A.J. Schaeffer. 1999. Treatment of urinary tract infections: what's old, what's new and what works", World J. Urol., vol.17, No.6, pp. 372-382.

Griebling, T.L. 2007. Urinary tract infections in women. In: Litwin M S, Saigal C S eds. Urologic diseases in America. Department of Health and human services, National institute of Diabetes and Digestive and Kidney diseases. Washington, D.C. GPO, NIH publication 07 - 5512: 587-619.

Hamdan, Z., Hamdan, et al. 2011. Epidemiology of urinary tract infections and antibiotic sensitivity among pregnant women at Khartoum north hospital" Annals of Microbiol. Antimicrobials, 10: 2.

Hart, A., T. Pham, S. Nowiciki, et al. 1996. "Gestational pyelonephritis associated Escherichia coli isolates represents non random- closely related population" American J. Obstetrics \& Gynecol., vol.1748, No.3, pp. 983-989.

Kolawole, A.S., O.M. Kolawole, Y.T. KandakiOlikemi, S.K. Babatunde, et al. 2009. Prevalence of urinary tract infection among patients attending Dalhatuaraf specialist hospital, Lafia, Nasarawa state, Nigeria." Int. J. Medicinal Med. Sci., vol.1, No.5 pp.163-167.

Manjula, N.G., Girish, C., Math, et al. 2013. Incidence of urinary tract infections and its etiological agents among pregnant women in Karnataka region. Adv. Microbiol., 3: 473-478.

Masinde, A., Gumodoka, B., Kilonzo, A., Mshana, S.E. 2009. Prevalence of urinary tract infection among pregnant women at Bugando medical centre, Mwanza, Tansania. Tanzan J. Health Res., 11(3): $154-9$.

Nowiciki, B. 2002. "Urinary tract infections in pregnant women; old dogmas and current concepts regarding pathogenesis", Curr. Infect. Dis. Reports (Italic), Vol 4, No.6, pp. 529-535.

Omonigho, S.E., Obasse, E.E., Akukalia, R.N. 2001. In vitro resistance of urinary isolates of Escherichia coli and Klebsiella spp. to Nalidixic acid. Niger J. Microbiol., 15(1): 25-29.

Schappert, S.M., Rechtsteiner, E.A. 2006. Ambulatory medical care utilization estimates for 2006. National health statistics report.

Theodore, M. 2007. Prevalence and antibiogram of urinary tract infections among prison inmates in Nigeria", The Int. J. Microbiol., Vol. 3, No.2.

Urinary tract infections in adults. National kidney and urologic diseases information clearing house, US Department of Health and Human services.

Wing, D.A. 1998. "Pyelonephritis". Clin. Obstretic Gynecol., 41(3): 515-526.

\section{How to cite this article:}

Anjaleena, T.G., O. Sasikumari and Gopakumar, T. 2017. A Study on the Bacterial Profile of Urinary Tract Infection in Antenatal Cases Attending a Tertiary Care Unit. Int.J.Curr.Microbiol.App.Sci. 6(7): 2419-2424. doi: https://doi.org/10.20546/ijcmas.2017.607.286 